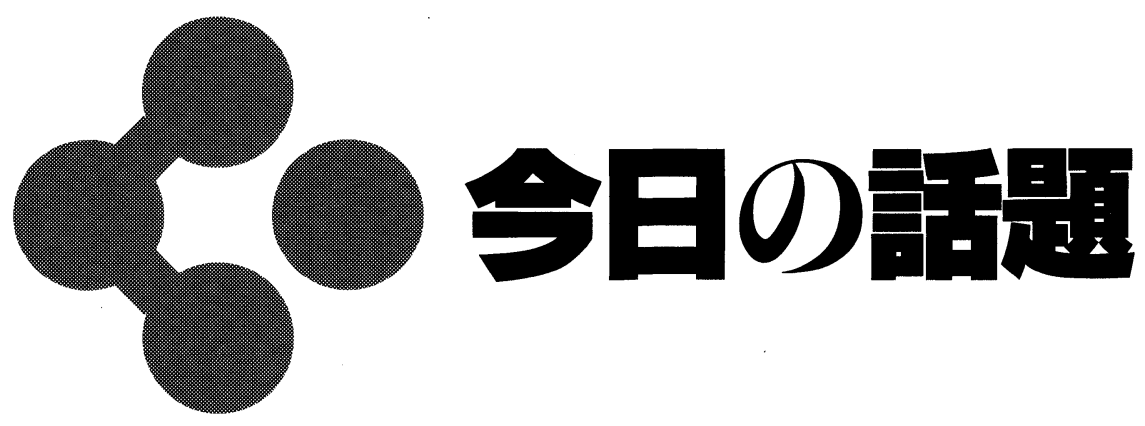

\title{
遺伝子として機能する蛋白質 “発茾酵母”におけるプリオンとその複製機構
}

通常，DNA や RNA が遺伝的な情報を伝達し，蛋白 質は酵素反応を行なうとされている。しかし，十数年前 に触媒活性能をもつ RNA 分子が発見された。また最近 になって，筆者らは発芽酵母における 2 つ現象が，核 酸ではなく蛋白質遺伝子に基づいていることを見いだし た(1). ある蛋白質が特定の高次構造をとると，自己複製 能をもつようになり, “遺伝子”として機能するのであ る.

発芽酵母における細胞質遺伝子(染色体外因子)である [URE3] および [PSI] は，いずれも 30 年ほど前に発見 された ${ }^{(2,3)}$.この 2 つの細胞質遺伝子は，核酸分子の(現 われによるものではなく，その実態は自己増殖できる ように変化した蛋白質であることが明らかになってき た ${ }^{(1)}$. [URE3] は Ure2p ( $\mathrm{p}=$ 蛋白質) という転写制御 因子の, [PSI] はSup35p という翻訳停止因子の変形 型である. Ure2p と Sup35p はいずれも染色体上遺伝子 URE2 と SUP35 にそれぞれコードされている.

ところで，ヒッジのスクレイピー，ヒトのクロイッフ エルトヤコブ病, 狂牛病などの海綿状脳症は感染性蛋白 質が原因と仮定されており, PrP という蛋白質がスクレ イピーの感染に必要であることが証明された ${ }^{(4)}$ 。このよ うな蛋白質をプリオンと呼び，プリオンが細胞内でいっ たん生じてしまうと，正常型蛋白質はすべてプリオン型 に変えられてしまうと言われている. しかし, 哺乳類を 使ってこの仮説を証明するのは難しく，未だに多くの疑 問が残っている(5).

そこで筆者らは，酵母を用いてプリオンを同定するた
めの 3 つの遺伝学的な規準を提案した ${ }^{(1)}$. (1)プリオンで あれば，それを除去しても，除去株にプリオンが再び低 頻度で出現するはずである. (2)その正常型蛋白質を過剩 発現させると, プリオンの出現頻度が増加するはずであ る. (3)プリオンの保持に必要な遺伝子（すなわち, 正常 型蛋白質をコードする遺伝子) の変異株の表現型は, プ リオンが生じる表現型と同一であるはずである.

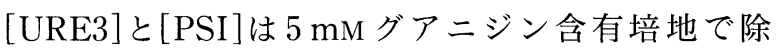
去されるが, 除去された菌株から低頻度でこれらの細 胞質因子が再発する(規準(1). Ure2p やSup35p を細 胞内で過剩発現させると, [URE3]や[PSI]の出現頻度 がそれぞれ 100 倍ほど増加する(規準 (2))。URE2 は [URE3], SUP35 は[PSI]の增殖に必要で, ure2 変異 株は[URE3]株, sup35 変異株は[PSI]株の表現型と同 じである(規準(3))。このように, [URE3]および[PSI]は プリオンの遺伝学的な規準をすべて満たす(図 1).

さらに，プリオンをもつ菌株から抽出されたUre2p と Sup35p は, 正常蛋白質とは異なった性質を示すはずで ある. 実際に, 正常 Ure2p はプロテアーゼで容易に分 解されてしまうが, [URE3]をもつ菌株から抽出された Ure2p は, プロテアーゼに対して抵抗性をもつように変 化していた. [PSI]をもつ菌株では, Sup35pの集合体 形成がみられる(後述)。したがって, [URE3]および [PSI]がプリオンであることは確かと思われる.

Ure2p を過剩発現させると, [URE3]が高頻度で出現 する(規準(2))。この活性を支配する Ure2p の領域は，ア ミノ酸残基 $1 \sim 65$ に相当し，これをプリオン領域と呼ん 
(1). 可逆性除去：

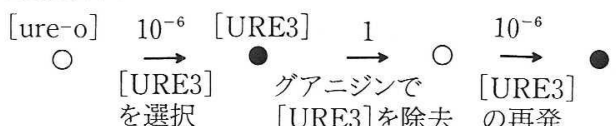

(2).Ure2p過剩発現により[URE3]頻度増加：
$\underset{\left[\begin{array}{cc}\odot \\ \text { ure-o] }\end{array} \stackrel{10^{-6}}{\longrightarrow}\right.}{\stackrel{10^{-4}}{\longrightarrow}} \stackrel{\bullet}{[\text { [URE3] }}$
Ure2pを過剩発現
させた $[$ ure-o]菌株

(3).プリオンと遺伝子の表現型関連：

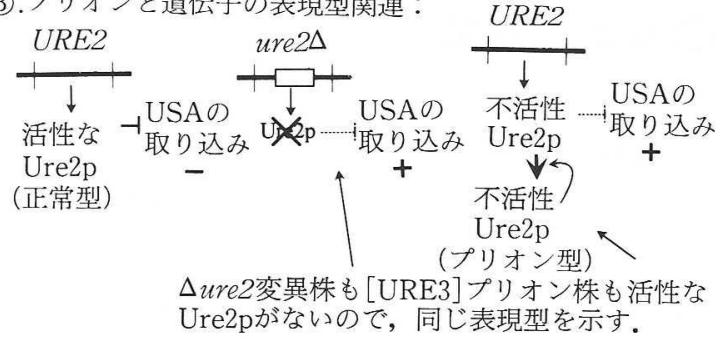

図 1 ロプリオンを同定するための遺伝学的規準

USA(ウレイドコハク酸)の細胞内への取り込みは Ure2pによっ て抑制される。

でいる(図 2)。プリオン領域の欠失した Ure2p は，窒素 源制御の機能は果たすが，プリオン型には変換できな い(6).したがって，[URE3] プリオンの繁殖は，2つのプ リオン領域間の相互作用で生じると考えられる。さ に, Ure2p の C 末端を欠失させると, 野生型に比べ 100 倍以上の[URE3]出現誘導能をもつようになる。同様 に, Sup35p の過剩発現が[PSI]の出現頻度を増加させ ることから， $\mathrm{N}$ 末端側(1〜114アミノ酸残基)が Sup $35 p$ のプリオン領域であることが示された ${ }^{(7)}$.

一方，in vitroで Ure2p はアミロイド纎維を形成す る.アミロイドの定義は, 繊維構造で $\beta$-シートをもち, プロテアーゼ而性を示し，コンゴーレッド染色により緑 色の複屈折を示すことである.Ure2p のプリオン領域 は，そ机自体でアミロイド繊維を形成し，さらに酵母か ら精製された全長の Ure2pのアミロイド形成を開始す る(8).したがって，[URE3]は自己増殖性 Ure2p アミロ イドであるとの仮説が出された ${ }^{(8)}$. 大腸菌から精製され た Sup35pも，in vitroで $\beta$-シート構造を示す繊維を 形成するが，コンゴーレッド染色により緑色の複屈折は 示さない(9).

Hsp104（熱ショック蛋白質の一種）というシャペロン は, [PSI]の次世代への伝達に必要とされる宿主因子で ある。しかし，Hsp104 を過剩発現させると，逆に[PSI]

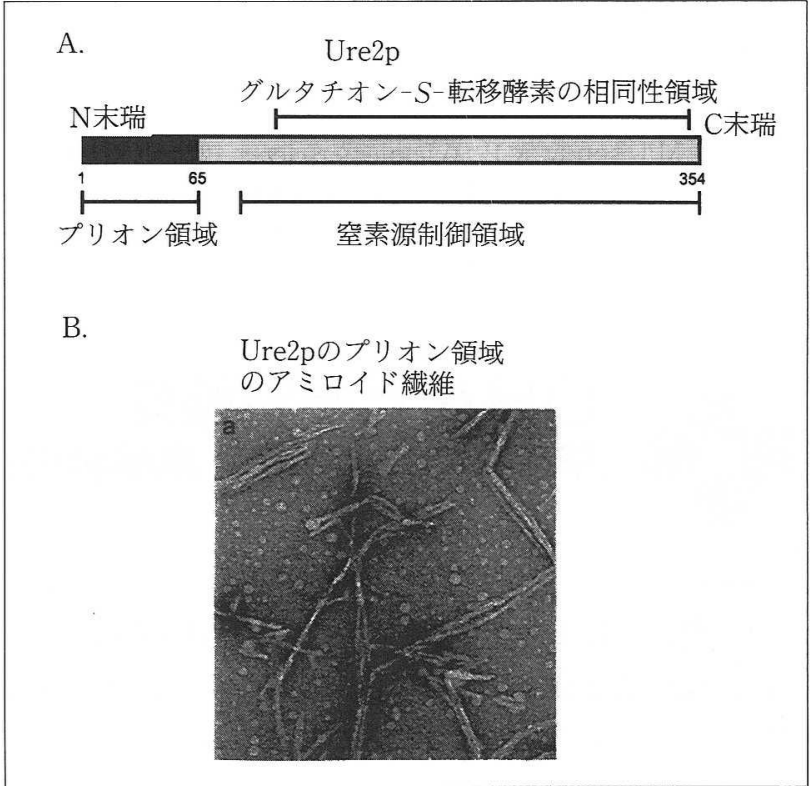

図 2 『Ure2pのプリオン領域および窒素源制御領域 (A) と Ure2p プリオン領域が生じるアミロイド瀻維（B)

が除去されてしまう(10). 本来，Hsp104 は集成された蛋 白質を適度に可溶化する機能をもち，[PSI]の複製に正 因子として働くが, 過剩発現させるとSup35p 繊維を 過度に溶解してしまうために[PSI]がなくなると考えら れる. [PSI]が細胞分裂に伴って分配されるためには， Sup35p の繊維が部分的に溶かされることが必要である のかもしれない。

最近，Podospora というカビから[Het-s]というプリ オンが発見された(11)。この場合，[Het-s]プリオンをも つ菌株だけがへテロカリオン不和合性（異なった遺伝子 型をもつ細胞の間では融合が起こらない現象）を示す。 カビに感染するウイルスの伝播を防止できるという点 で，この現象は生存に有利と思われる ${ }^{(11)}$. 今後はプリオ ンが関与している生命現象がもっと見つかるかもしれな い。原因不明な難病として哺乳動物から発見されたプリ オンが，酵母やカビからも見つかった事実は，プリオン 蛋白質の生物界での広い分布を示唆している。一方，ア ミロイドは蛋白質の特殊纎維構造で, アルツハイマー 病, 糖尿病やスクレイピーなどの原因となる。[URE3], [PSI]㧍よび[Het-s]の研究は，このようなヒトの難病 を理解するためにも重要な学問分野ではないかと思われ る.

1) R.B. Wickner: Science, 264, 566 (1994).

2) B.S. Cox : Heredity, 20, 505 (1965). 
3) F. Lacroute : J. Bacteriol., 106, 519 (1971).

4) C. Weissmann : J. Biol. Chem., 274, 3 (1999).

5) B. Caughey \& B. Chesebro: Trends Cell Biol., 7, 56 (1997).

6) D.C. Masison \& R.B. Wickner: Science, 270, 93 (1995).

7) Ter-Avanesyan, A.R. Dagkesamanskaya, V.V. Kushnirov \& V.N. Smirnov : Genetics, 137, 671 (1994).

8) K.L. Taylor, N. Cheng, R.W. Williams, A.C. Stevens \& R. B. Wickner: Science, 283, 1339 (1999).
9) J.R. Glover, A.S. Kowal, E.C. Shirmer, M.M. Patino, J.J. Liu \& S. Lindquist : Cell, 89, 811 (1997).

10) Y.O. Chernoff, S.L. Lindquist, B.-I. Ono, S.G. Inge-Vechtomov \& S.W. Liebman : Science, 268, 880 (1995).

11) V. Coustou, C. Deleu, S. Saupe \& J. Begueret: Proc. Natl. Acad. Sci. USA, 94, 9773 (1997).

(宇育奈理努 (Reed B. Wickner), 森山裕充, 米国国立 衛生研究所・国立糖尿病消化器系腎蔵病研究所)

\section{을 ¿視覚機能 早産児の視力発達, 高齢者の視力回復などに効果}

DHA（ドコサヘキサエン酸，22:6n-3）は，魚介類の 脂質に豊富に含まれている。また，ヒトや陸上動物では， 脳, 網膜, 精巣などの脂質に多く認められている. 特に 脳では, シナプス膜の脂質にも存在しておりり, その機能 と関係していると考えられている(1).

DHA の生理機能としては, 心血管系疾患の予防効果, 脳の発達促進作用, 記憶学習能の維持向上作用, 痴呆症 の改善効果, 精神安定化作用, 抗腫瘍作用, 抗炎症作用の 他, 視覚機能の維持向上作用が知られており ${ }^{(1)}$, 最近で は，視力に及ぼす DHAの効果が検討されている。

DHA と視覚機能についての研究では， $\alpha$-リノレン酸 が豊富なシソ油とリノール酸が豊富なサフラワー油をそ れぞれ含む飼料でラットを母仔 2 世代にわたり飼育し, その網膜の反射能を調べた結果，サフラワー油食の仔ラ ットに比べ，シソ油食の仔ラットは網膜リン脂質中の DHA の割合が高く, 網膜電位図の $\mathrm{a}$ 波および $\mathrm{b}$ 波が大 きく，反射能が高いことが認められている(2).

ヒトを対象にした研究では, 早産児の視力の発達と DHA 摂取との関係について検討した結果が報告されて いる。超低体重児に魚油と大豆油を含む人工乳を与えた 場合，視覚性誘発電位の鋭敏性は DHA を含む母乳の場 合とほぼ同じであり，コーン油や大豆油をそれぞれ含む 人工乳を与えた場合より高く, 網膜電位反応もコーン油 を含む人工乳より魚油と大豆油を含むものを与えた場合 のほうが鋭敏であることが明らかにされている(3).また， Teller 視力カード法（白黒格子のカードの位置を認識で きるか否かの検査）で検討したときも, 魚油を含む人工 乳の摂取は 4 力月目までの早産児の視力を改善し(4), Fagan テスト (視覚的注意力の検査)でも, DHA 添加の 人工乳を生後 2 力月まで与えた早産児で, 慣れ親しんだ 物の絵によく注意を注ぐことも報告されている ${ }^{(5)}$ ささら
に, 正常出産児でも, DHA を含む母乳を与えられたもの のほうが，人工乳を与えられたものより網膜反射能が高 く, DHA を人工乳に添加したものを与えると, その視覚 機能は母乳児のレベルまで改善することが知られてい る(6).

最近では, 小学生程度の子供から若者の視覚機能と DHA 摂取の関係について検討した結果 ${ }^{(7)}$ が発表されて いる. 対象は, 視力が 1.0 以下の 4 歳から 22 歳までの 近視者 27 名(男性 7 名，女性 20 名）とし，この被検者に DHA 含有パン (300 mg DHA/日)を 1 力月間毎日捸取 させ,パン摄取前後の視力の変化を測定した.その結果, 左右どちらかの視力が 0.2 以上向上した者は 11 名（約 $41 \%$ ）であった。 また，このとき，男女による差は認め られなかった。

さらに，1 カ月で視力が向上した者のうち 6 名につい て DHA 含有パンの長期間捸取による効果について検討 したところ，5名が改善した視力をさらに 5 力月間維持

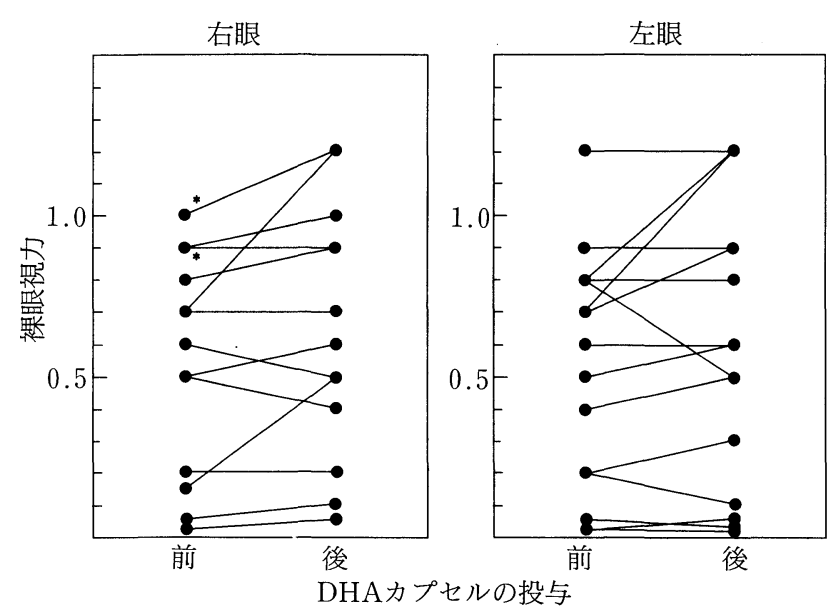

図 1 -高齢者の裸眼視力に及ぼす DHA の効果 *2 眼分のデータを含む. 
することができた. しかし，1名は DHA 含有パンの摂 取をやめてしまったため, 視力は維持できず元のレベル まで低下した。また，1 カ月で視力が向上しなかった者 のうち 7 名について同様の検討を行なったところ，視力 の向上が認められたのは 1 名だけであった。これらの結 果は, DHA の搨取により, 近視の視力改善効果が認め られる人は, 1 力月で効果が出るが，1力月で効果が認め られない近視者は，長期間摂取しても効果が期待できな いことを示していると考えられる．さらに，向上した視 力を維持するためには, DHA を継続して摂取する必要 があることを示しているものと思われる(7).

また, 高齢者 15 名 (男性 1 名, 女性 14 名, 平均 72 歳) を対象とした研究では，被検者に DHA カプセル (540 $\mathrm{mg} \mathrm{DHA} /$ 日) 3 カ月間毎日摂取させ, DHA カプセル 摄取前後の視力の変化を測定した。このときの被検者 は, 白内障患者, 緑内障患者, 両疾患合併症の患者であ った． 総合的な視力が上昇した場合を改善効果ありと判 定した。その結果，15名中 10 名（約 $67 \%$ ）に改善効果 が認められた。疾患別では, 白内障患者 11 名中 8 名, 緑 内障患者 1 名中 1 名, 両疾患合併症の患者 3 名中 1 名で 視力が改善した。被検者の中には, 0.7 の裸眼視力が
1.2 に向上した者もいた(図 1).これらの結果は，高齢 者でも DHA 捸取により視力が向上する可能性が高いこ とを示しているものと思われる(8). しかし,この結果は, DHA の摂取により，白内障や緑内障が治癒したためで はなく, 網膜や視神経の機能が向上したことによると考 えられる。

今後は, DHA の視力向上効果のメカニズムを解明す ることや, 糖尿病性網膜症における DHA 摂取の有効性 について明らかにする必要があるものと思われる.

1）原 健次: “生理活性脂質 EPA•DHA の生化学と応用”, 幸書 房, 1996.

2) I. Watanabe, M. Kato, H. Aonuma, A. Hashimoto, Y. Naito, A. Moriuchi \& H. Okuyama: Adv. Biosci., 62, 563 (1987).

3) E.E. Birch, D.G. Birch, D.R. Hoffman \& R.D. Uauy : Invest. Ophthalmol. Vis. Sci., 33, 3242 (1992).

4) S.E. Carlson, S.H. Werkman, P.G. Rhodes \& E.A. Tolley : Am. J. Clin. Nutr., 58, 35 (1993).

5) S.E. Carlson \& S.H. Werkman : Lipids., 31, 85 (1996).

6) M. Makrides, M.A. Neumann \& R.A. Gibson : Lipids, 31, 115 (1996).

7）高橋英敏，片岡 久，鈴木平光：脂質栄養学，6, 166 (1997)

8）高橋英敏, 鈴木平光, 片岡 久: 脂質栄養学, 8, 115 (1999).

（鈴木平光，農林水産省食品総合研究所）

\section{ค Gas6：r-カルボキシグルタミン酸ドメインをもつ細胞増殖因子 受容体トリプルノックアウトマウスからわかったこと．二価性細胞接着因 子の可能性}

細胞増殖因子は，細胞増殖のみならず細胞の生存維 持，分化，運動能の六進など，多様な生理活性をもち， その多くは分泌性蛋白質である，多くの細胞増殖因子は 細胞表面にある受容体型チロシンキナーゼに結合し，自 己リン酸化, 活性化させることによって，そのシグナル を細胞内へ伝達する. 最近, 受容体型チロシンキナーゼ Axl(Ark, Ufo とも呼ぶ), Sky(Rse, Tyro3, Brt, Dtk とも呼ぶ), Mer (Eyk, Nyk とも呼ぶ) のリガンドとし て新規な細胞増殖因子 Gas6 が同定された. Gas6 は $\gamma$ カルボキシグルタミン酸 (Gla) ドメインをもつ特徵的な 構造の細胞増殖因子で, その生理活性に関心が寄せられ ている.

Gla 残基は，グルタミン酸 (Glu) 残基がビタミン K 依 存性カルボキシラーゼによって $\gamma$ 位にカルボキシル基 が付加されたものである(図 1). Gla 残基のクラスター からなる Gla ドメインをもつ蛋白質としては, 血液凝固
因子（プロトロンビン，VII因子，IX因子，X因子など)， 血液凝固調節因子 (プロテイン $\mathrm{C}$, プロテイン $\mathrm{S}$ など), 骨形成に重要なオステオカルシンなどが知られている. これらの蛋白質の生理活性の発現には, Gla ドメインが 正常に形成されることが必要である. ビタミン $\mathrm{K}$ が欠乏 すると血液凝固因子の Gla 化が起こらず, 血液凝固能が 低下することはよく知られている. Gla ドメインは $\mathrm{Ca}^{2+}$ と結合し, 血液凝固系の蛋白質ではその結合により, 細 胞膜リン脂質との親和性が高まることが知られている.

Gas6 は, 繊維芽細胞の血清飢餓時に発現が誘導される 遺伝子として同定された growth arrest-specific gene 6 遺伝子の産物である ${ }^{(1)} . \mathrm{N}$ 末端に 10〜 11 個の Gla 残基 を含む Gla ドメインと 4 個の EGF 様ドメインをもち, $\mathrm{C}$ 末端に性ホルモン結合グロブリン (SHBG) と相同性の あるドメインをもつ(図 2).そのドメイン構造は抗血液 凝固因子として知られるプロテイン $\mathrm{S}$ と類似しており, 


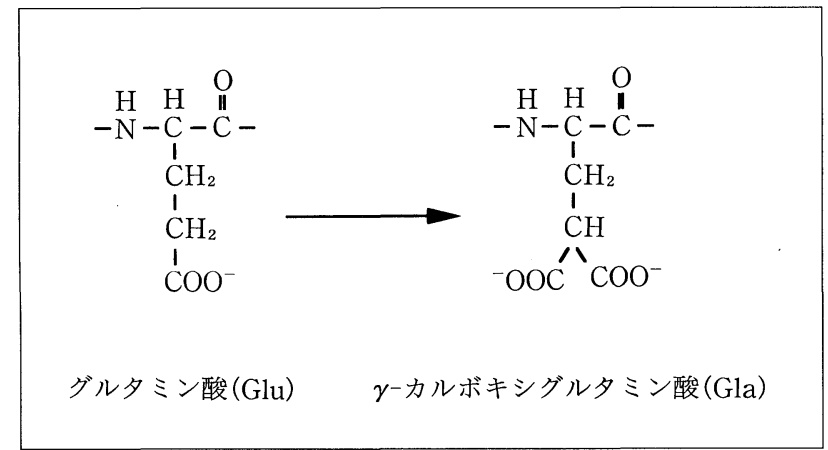

図 1 -ビタミン K 依存的 $\boldsymbol{\gamma}$-カルボキシル化

全体で 44\%のアミノ酸相同性をもつ. Gas6 は，血管平 滑筋細胞に対して増殖強化活性を示す。すなおち, Gas6 のみでは増殖活性はないが, トロンビンやリゾホスファ チジン酸など三量体 $\mathrm{G}$ 蛋白質共役型受容体を活性化さ せる因子による増殖を促進する活性をもつ ${ }^{(2)}$.また Gas6 は, 血管平滑筋細胞や繊維芽細胞に対して生存維持活性 を示す．血清飢餓時に発現誘導されることの生理的意義 は不明であるが，血清飢餓時の生存維持作用にあるのか もしれない．また，シュワン細胞に対しても増殖促進因 子として作用することが報告されている.

受容体型チロシンキナーゼ Axl, Sky，Mer は，N末 端部に 2 個のイムノグロブリン様ドメインと 2 個のフィ ブロネクチンタイプIIIドメインからなる特徵的な構造の 細胞外ドメインをもち，膜貫通ドメインを挟んで $\mathrm{C}$ 末端 部に細胞内チロシンキナーゼドメインをもつ(図 2)。こ れらは受容体型チロシンキナーゼの中で一つのサブファ ミリーを形成している，その過剩発現は細胞癌化を誘導 する. Axl, Mer は広い組織で発現しているのに対し, Sky は特に脳や精巣での高い発現が認められる. 1995 年, 複数のグループにより Axl, Sky, Merのリガンドが Gas6 であることが明らかにされた ${ }^{(3,4)}$. Gas6 はいずれの 受容体にも結合し，活性化させることができるが，結合 親和性は異なっており, Sky は Axlの $1 / 7$, Mer は Axl の $1 / 70$ 程度の親和性である (図 2) ${ }^{(4)}$. その生理的意義は 現在不明であるが, 共役する受容体やリガンドの存在, あるいは Gas6 に相同なリガンドの存在などが考えられ る。ちなみに，プロテイン $\mathrm{S}$ がこれらの受容体のリガン ドとして機能するか否かについては議論のあるところで はあるが，同種間での結合はきわめて低く（検出感度以 下), 生体内でリガンドとして機能するためには何か特 別のメカニズムが必要と思われる(3,4).

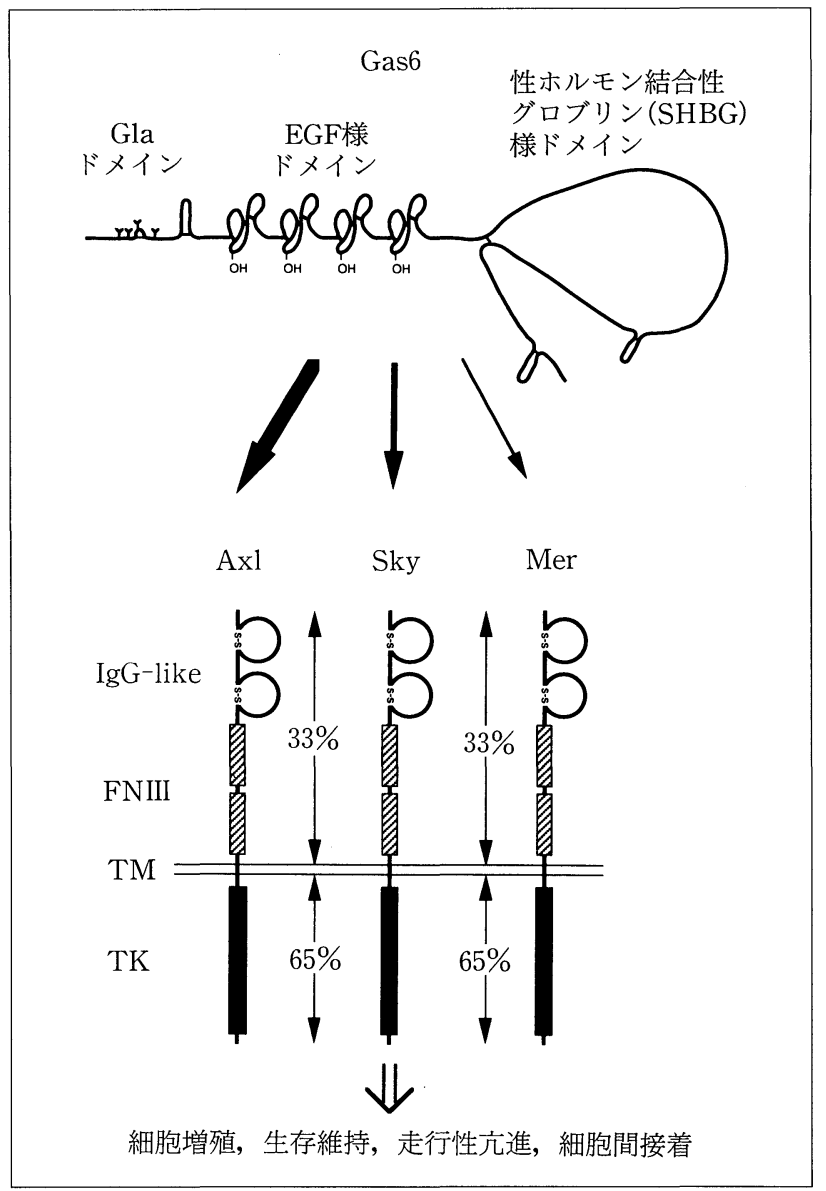

図 2 -Gas6 と光の受容体

$\mathrm{IgG}$ : イムノグロブリン様ドメイン, FNIII：フィブロネクチンタ イプIIIドメイン, TM : 膜貫通ドメイン, TK：チロシンキナーゼド メイン

最近 Lu らは，3 種の受容体 Axl, Sky, Mer すべてを 欠失したトリプルノックアウトマウスを作製し，その表 現型を報告した ${ }^{(5)}$ ここのマウスでは脳(海馬，小脳，大脳 皮質), 肝臓, 血管壁, 網膜などの変性, 退縮, 細胞死や 脾臓の肥大が観察された。また，雄では成熟精子を形成 できず不妊となる． 3 種の受容体は，精細管内の精子形 成細胞の栄養と支持に関わるセルトリ細胞に発現してお り, Gas6 は成熟前にはライディッヒ細胞で, 成熟後はラ イディッヒ細胞とセルトリ細胞に発現している。これら の結果から, Gas6 はライディッヒ細胞およびセルトリ 細胞から分泌され，セルトリ細胞の精子形成支持機能に 関与していると考えられる。 また，トリプルノックアウ トマウスの表現型はテストステロンを除去した場合とよ く似ているので, Gas6 は C 未端の SHBG 様ドメインに ステロイドホルモンを結合した複合体として作用する可 


\section{今日の話是 \&6}

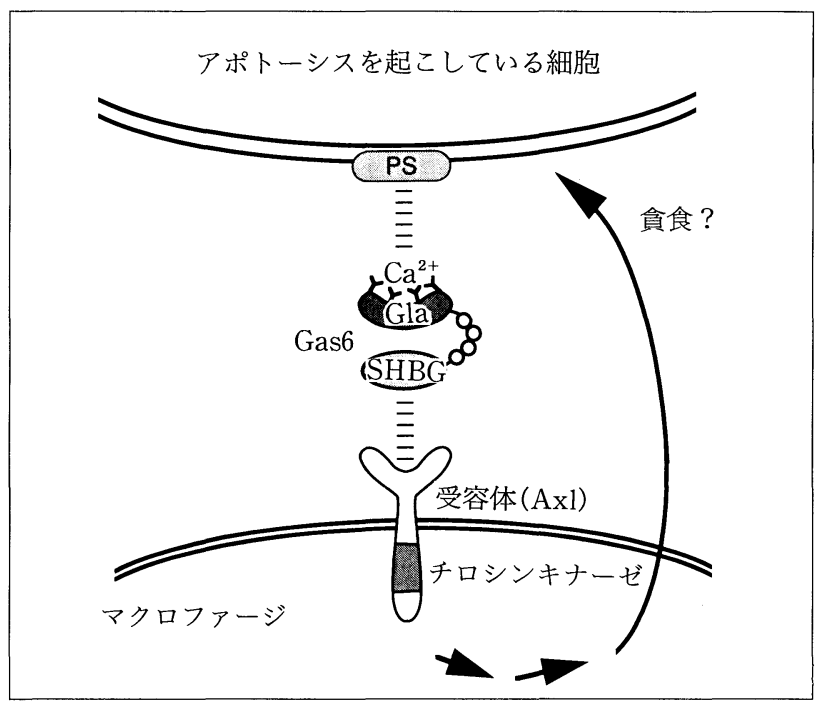

図 3 - Gas6 の二価性細胞接着モデル

Gas6 は，Gla ドメインを介してアポトーシス細胞膜表面のホスフ アチジルセリン（PS）を認識し，SHBG 様ドメインを介して Axl と結合する. Gas6 はこの二価性結合活性により，マクロファージ の貪食作用を六進している可能性が考えられる。

能性も考えられる.これまでに，ステロイドホルモンの 機能の一部は膜を通過せずに発揮されるといわれていた が, Gas6-Axl (Sky, Mer) 系を介した作用であるかも しれない.Gas6 のステロイド結合能を調べてみることは 興味深いと思われる. 3 種の受容体のうち，1種あるい は Sky/Axl，Sky/Mer を欠失しても異常は目立たない が，3種とも欠失すると多くの組織で異常がみられるこ とから，3種の受容体はそれぞれの機能を相補すること ができると考えられる。

Gas6 はビタミン K の拮抗剤であるワルファリン存在 下で発現させると， $\mathrm{N}$ 末端の Gla ドメインが形成されず Gluのままである.これは正常に Glaをもつものと比 べ, 受容体との結合活性は弱い。一方，Gla ドメインを
欠失した変異体の受容体結合活性は野生型の Gas6 と同 程度であるので，正常に Gla 化されていない Gas6では SHBG 様ドメインと受容体との結合に対して Gla ドメ インが分子内で阻害的に作用している可能性が考えられ る(6). Gas6 の Gla ドメインは, 生体膜を構成するリン脂 質の中でホスファチジルセリンと特異的に結合する. Axl を発現するU 937 単球芽細胞は Gas6 依存的にホス ファチジルセリンに結合することから，Gas6 は N 末端 の Gla ドメインを介してホスファチジルセリンを認識 し, C 未端の SHBG 様ドメインを介して Axl に結合す る二価性細胞間接着分子として機能すると考えられる (図 3) ${ }^{(7)}$. ホスファチジルセリンは老化した赤血球やア ポトーシスを起こす細胞では膜表面に配向することが知 られているので, Gas6 は Axl を発現するマクロファー ジがアポトーシスあるいは老化細胞を認識し貪食するの を六進する活性をもつ可能性が考えられる(図 3).

Gas6 は Gla ドメイン, SHBG 様ドメインという特徵 的な構造をもった新規な細胞増殖因子であり, 他の増殖 因子とは異なった生理作用や活性発現メカニズムがある ものと考えられ，今後の研究の進展が期待される。

1) G. Manfioletti, C. Brancolini, G. Avanzi \& C. Schneider : Mol. Cell. Biol., 13, 4976 (1993).

2）中野 亨: 蛋白質 核酸 酵素, 41, 1543 (1996).

3) 水野健作, 大橋一正：細胞工学, 15, 222 (1996)

4) K. Nagata, K. Ohashi, T. Nakano, H. Arita, C. Zong, H. Hanafusa \& K. Mizuno : J. Biol. Chem., 271, 30022 (1996).

5) Q. Lu, M. Gore, Q. Zhang, T. Camenisch, S. Boast, F. Casagranda, C. Lai, M. K. Skinner, R. Klein, G.K. Matsusima, H.S. Earp, S.P. Goff \& G. Lemke : Nature, 398, 723 (1999).

6) K. Tanabe, K. Nagata, K. Ohashi, T. Nakano, H. Arita \& K. Mizuno: FEBS Lett., 408, 306 (1997).

7) T. Nakano, Y. Ishimoto, J. Kishino, M. Umeda, K. Inoue, K. Nagata, K. Ohashi, K. Mizuno \& H. Arita : J. Biol. Chem., 272, 29411 (1997).

(大橋-永田恭子, 水野健作, 東北大学大学院理学研究科)

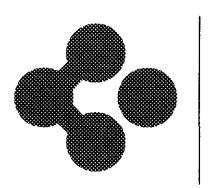

高等植物は, 光合成により得た同化産物を生長に応じ て適切に再配分することにより，自己のエネルギーバラ ンスを調節している。同化産物(糖)の転流はスクロース の形で維管束篩部を介して行なわれている．最近，制御 様式も含めたその分子機構が急速に明らかになりつつあ
る. 本稿では, この分野の研究の近況を紹介したい. 高等植物では, 緑葉などの光合成によって得た同化産 物を送り出す側を「ソース」, 貯蔵器官などそれを受け取 る側を「シンク」と呼んでおり, ソースからシンクへの 同化産物の転流は従来, “濃度勾配による拡散”で説明 


\section{ร日の)話题 80}

されてきた. しかし実際には，この仮説にあてはまらな いケースも多い. 特に, ソース組織における細胞外（ア ポプラスト）から篩管（細胞内；シンプラスト）へのス クロースの取り込み過程は濃度勾配に反して行なわれる ことから, トランスポーターなどの何らかの能動的輸送 機構の存在が不可欠と考えられていた(図 1).

そのような状況下で，1992 年 Riesmeier らは細胞外 のスクロースを栄養源にできない酵母変異株にホウレ ンソウの cDNA 発現ライブラリーを組み込む，いわゆ る機能相補実験を行ない, 初めてスクローストランスポ ーターの単離に成功した (SoSUT1; Spinacia oleracea sucrose transporter $)^{(1)}$. その後, 同様の方法や cDNA 塩基配列の相同性をもとに, 現在までにシロイヌナズ ナ, バレイショ, オオバコ, タバコなどから 10 種類以上 のスクローストランスポーター遺伝子 (以後, $S U T$ ) が 単離された，そのいずれもが動植物や酵母の単糖トラン スポーターと同様, 12 回の膜貫通ドメインを有する膜夕 ンパク質であった。これらのトランスポーターは膜に局 在する $\mathrm{H}^{+}$-ATPase と共役して, プロトン濃度勾配を駆 動力にスクロースの能動輸送を行なっていると考えられ ている(図 1).バレイショにおけるSUT(StSUT1)の
アンチセンス形質転換体は，緑葉中におけるスクロース 濃度の増加とデンプン含量の増加，塊茎重の低下などの 特徴を示したことから，ソースからシンクへのスクロー スの転流にこのトランスポーターが重要な役割を果たし ていることが示された ${ }^{(2)}$.

$S U T$ 遺伝子は各植物種あたり 1〜数コピー見いださ れており, 緑葉や花芽, 発達途上の子葉, 貯蔵器官など での発現が報告されている．基本的には，ソースから維 管束へ輸送するタイプと維管束からシンクへ輸送する夕 イプが存在すると予想され，低コピー数ながらも普遍的 にショ糖輸送に関与していると推定されている。このこ とは, 主として単糖を輸送する単糖トランスポーターが 比較的多コピーで維持され，各々が時期・組織特異的に 発現して糖需要に対応していると考えられているのとは 対照的である。

SUT の生合成に関しては従来伴細胞で mRNA が翻 訳された後, 原形質連絡を介して篩管細胞へ移動すると 考えられていた，しかし，䇻管細胞内においても SUT の mRNA が検出されたという報告があり，翻訳が篩管 内で行なわれている可能性も否定できない(3). ただし， 核や rRNA を欠く篩管細胞ではたして翻訳が可能か?

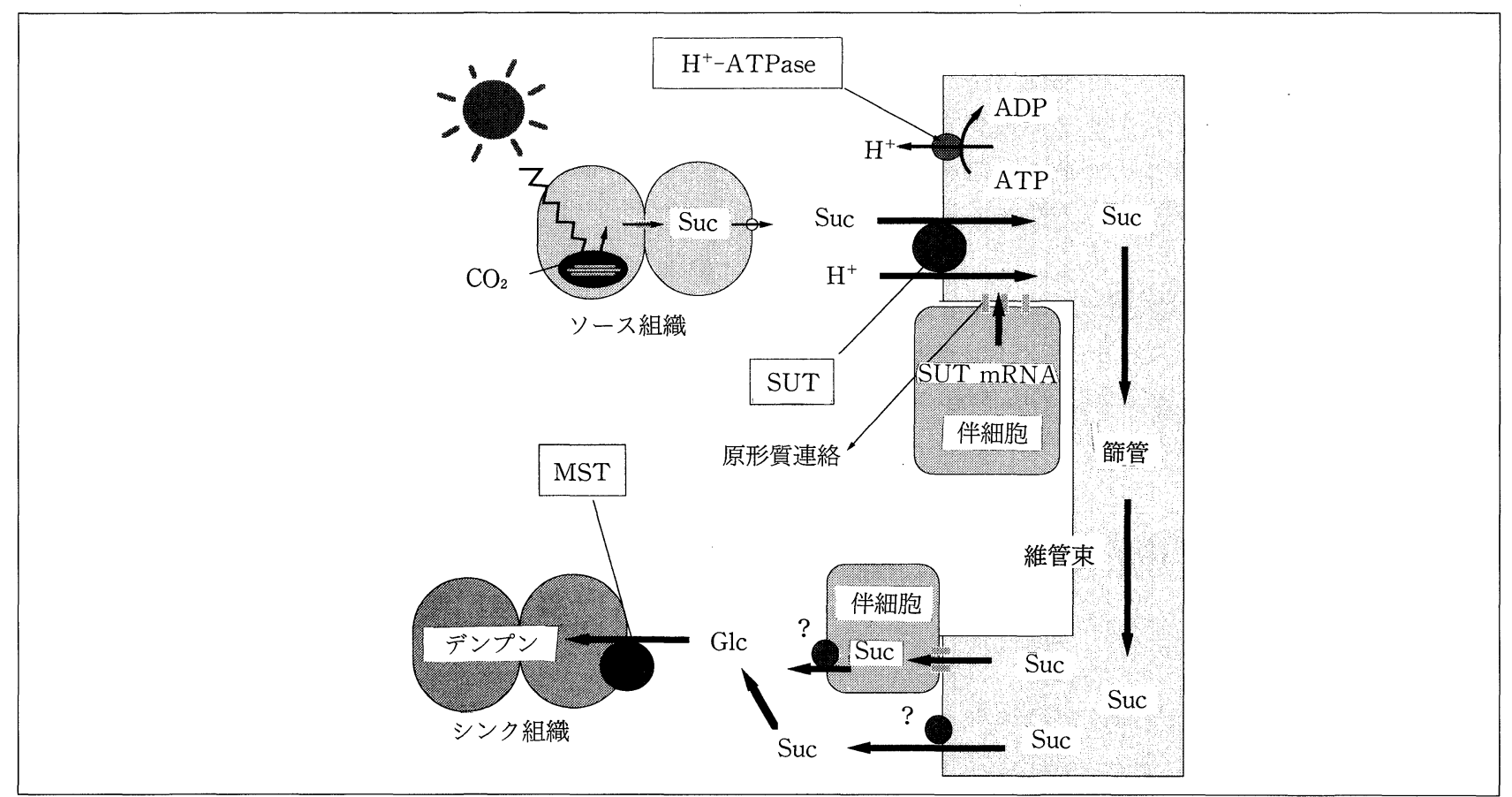

図 1 ロ高等植物における同化産物の輸送のモデル図

SUT : スクローストランスポーター, MST : 単糖トランスポーター, Suc：スクロース, Glc : グルコース. SUT は H ${ }^{+}-\mathrm{ATPase}$ と共役し て $\mathrm{H}^{+}$の濃度勾配を利用して篩管へスクロースを取り込んでいる. 維管束からシンク組織へのスクロース輸送は依然不明の部分が多い. 

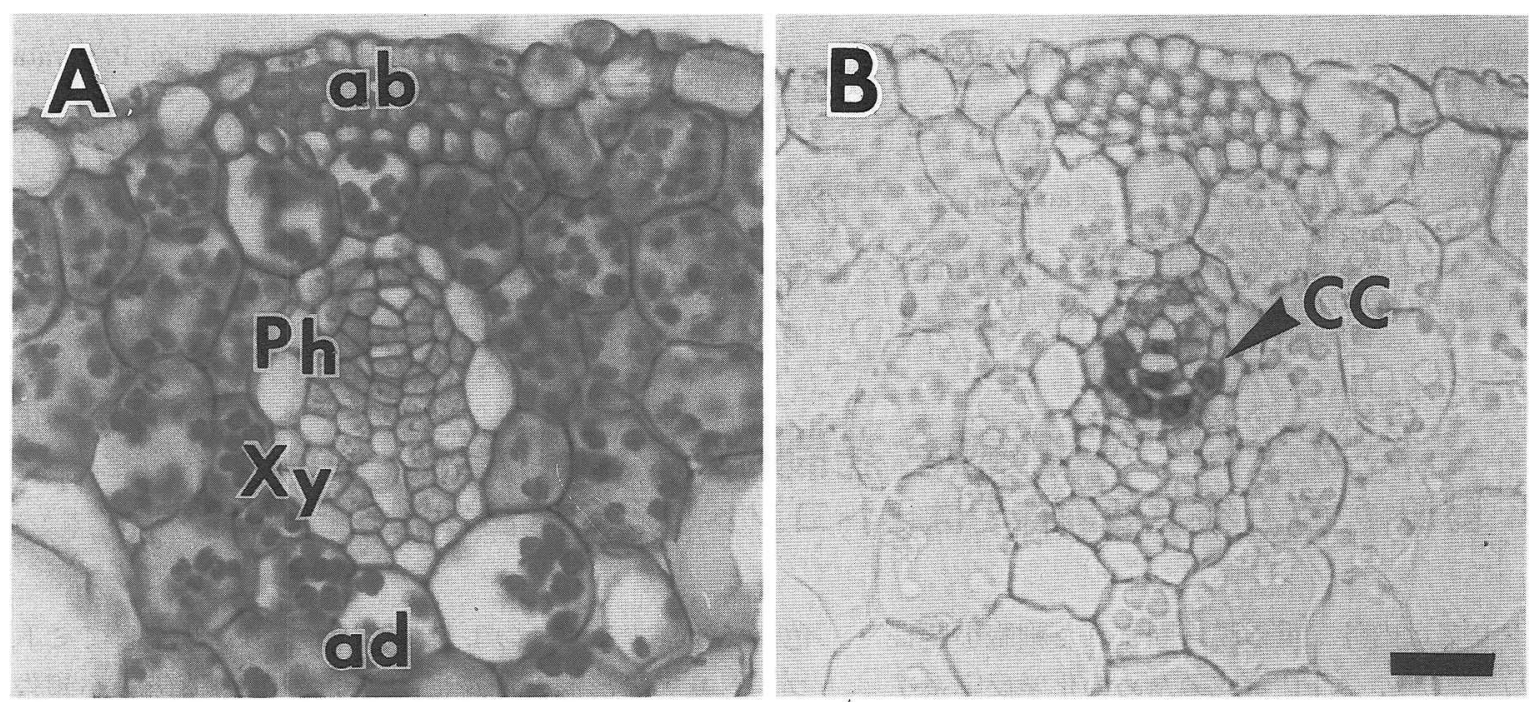

図 2 日葉鞘維管束における OsSUT1 の発現

A：PAS デンプン染色を行なったイネ葉鞘の横断切片。細胞内デンプン顆粒と細胞壁が染まる. B : OsSUT1 をプローブにin situハイ ブリダイゼーションを行なったもの. 2 枚の写真は連続切片の同じ維管束部分を拡大したもの.SUT は篩部伴細胞特異的に発現している (矢頭)。 $\mathrm{ab}$ ：背軸側 (葉の外側), $\mathrm{ad}$ : 向軸側 (同内側), $\mathrm{Ph}$ : 維管束篩部, $\mathrm{Xy}$ : 維管束木部, $\mathrm{CC}$ : 篩部伴細胞.

という議論もあり，詳細は依然明らかではない。さらに 最近, StSUT1 の発現が mRNA レベルで光による調節 を受けることも明らかにされた ${ }^{(3)}$ 。このタイプの SUT は, 昼間に発現し同化産物の転流に機能するタイプと推 定される。従来, トランスポーターは細胞膜上で常に量 的に一定レベルで維持され機能していると考えられてき たが，これらの結果は環境条件に細かく対応しながら， 主として転写レベルで調節されていることを示してい る。

こうした研究は，主として双子葉植物で進められてお り, 主要作物を含む単子葉植物の SUT に関する情報は 非常に乏しいのが現状である。筆者らはイネの発芽に伴 う糖代謝の研究を行なってきたが，その中で初期伸長過 程における葉鞘で維管束系を介した糖転流が活性化され ることを報告した ${ }^{(4)}$.そこで, 糖転流の動態をより詳細に 解析する目的で広瀬ら ${ }^{(5)}$ によイネ緑葉から単離され た OsSUT1 (Oryza sativa L. sucrose transporter 1) に注目してその発現解析を試みた。OsSUT1 は,アミノ 酸レベルで双子葉のSUT と 45〜 77\%の相同性を示し， 発芽種子, 出穂期の葉, 登熟中の穂などで強い発現を示 す. 詳細な in situ mRNA 検出を行なった結果, 維管束 の篩部伴細胞(図 2) おょび゙登熟途中の肧乳表層細胞で mRNA のシグナルが確認された。このことは, OsSUT1 が篩管を介したスクロースの転流を司るとともに, 胚乳 などのシンク器官の発達にも寄与していることを示唆し
ている。

筆者らはさらに，単離肧を用いて OSSUT1 の同化産 物 (糖)に対する応答を調查した ${ }^{(6)}$ 。単離胚は玄米から肧 乳を取り除いたもので, 人工培地上で発芽・培養するこ とにより, 組織内糖濃度を任意に調節できるという利点 がある。ノーザン解析の結果, OSSUT1 は発芽後比較 的早い段階から光により，また光の影響を除いた暗条件 下で培養 3 日目以降, 糖単独により転写が誘導されるこ とが確認された。維管束特異的な SUT が光により発現 誘導を受けることはすでに述べたが(3)，今回新たに糖に よる発現調節が確認されたことで, 維管束系を介した糖 転流が光と糖による複合的な調節を受けていることが示 された。たとえば，ソラマメの子葉形成時に発現する VFSUT1 はOSSUT1 とは異なり, 糖により転写抑制を 受けることが報告されている(7)。このような応答性の相 違を説明するものとしては, 各組織・器官, 多重遺伝子 族, 植物種による SUT の発現制御や糖転流の調節様式 の違いなどが考えられるが, その詳細は今後の研究課題 である。

最近, 糖は植物の分化・生長や代謝調節に関与するシ グナル物質としても注目を集めておりり ${ }^{(8)}$, 今回述べてき た研究の進展が糖シグナル伝達機構解明の端緒となるこ とを期待したい。

1) J.W. Riesmeier, L. Willmitzer \& W.B. Frommer : $E M B O$ J., 11, 4705 (1992). 
2) J.W. Riesmeier, L. Willmitzer \& W.B. Frommer : $E M B O$ J., 13, 1 (1994).

3) C. Kuhn, V.R. Franceschi, A. Schulz, R. Lemoine \& W.B. Frommer: Science, 275, 1298 (1997).

4) C. Matsukura, S. Itoh, K. Nemoto, E. Tanimoto \& J. Yamaguchi : Planta, 205, 145 (1998).

5) T. Hirose, N. Imaizumi, G.N. Scofield, R.T. Furbank \& R. Ohsugi : Plant Cell Physiol., 38, 1389 (1997).

\section{今日の話题}

6) C. Matsukura, T. Saitoh, T. Hirose, R. Ohsugi, P. Perata \& J. Yamaguchi：論文投稿中.

7) H. Weber, L. Borisjuk, U. Heim, N. Sauer \& U. Wobus : Plant Cell, 9, 895 (1997).

8) P. Perata, C. Matsukura, P. Vernieri \& J. Yamaguchi : Plant Cell, 9, 2197 (1997).

(松倉千昭, 山口淳二, 名古屋大学生物分子応答研究セ ンター)

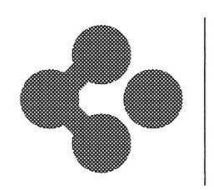

ミトコンドリアは内外二重の膜に囲まれた細胞小器官 (オルガネラ）であり，ATP 合成のための化学反応系を 含んでいる。ミトコンドリアは独自の DNA (mtDNA) とタンパク質合成系を保持して抢り，ミトコンドリア核 分裂を伴って分裂する ${ }^{(1,2)}$. 現在，ミトコンドリア分裂装 置の実体が明らかにされつつあるが(2)，ミトコンドリア の形態や細胞内分布がどのように制御されているかにつ いては，まだ不明な点が多い。

筆者らは出芽酵母 Saccharomyces cerevisiae を用い て, 出芽, 減数分裂, 胞子形成, 接合, 発芽など生活環 の様々な過程において，ミトコンドリアが相互に融合し て枝分かれした紐状または網状の形態をとることを報告 してきた ${ }^{(3,4)}$. 出芽中の酵母では, 融合ミトコンドリアは 細胞表層下に位置しており，ミトコンドリアの先端が芽 の中に移動する (図 1)。また, 胞子形成過程では, 発達 した網状ミトコンドリアは, 減数分裂核と一定の位置関 係を保ちながら形態を変化させ，4つの胞子に分配され る(3,4). 網状に融合したミトコンドリアは他種酵母でも みられる(5)。

1991 年以降, いくつかの研究室でミトコンドリアの形 態・伝達に異常を示す突然変異体が分離されてきた ${ }^{(6)}$.

S. cerevisiae では mtDNA が失われて呼吸能が欠損し ても, グルコースを炭素源とする培地で発酵により生育 できる。このような場合でも，ミトコンドリアの二重膜 構造自体は子孫に伝達されている。しかし，ミトコンド リアは呼吸以外にも細胞に必須な機能を担っているた め，ミトコンドリアをまったく伝達できない酵母は致死 となる。 そこで, 変異原処理した酵母から温度感受性突 然変異体を数千個とり，これらを 1 株ずつ許容温度と制 限温度で培養して，ミトコンドリアの形態を膜電位依存 性螢光色素 $\mathrm{DiOC}_{6}$ (3) や DNA 結合螢光色素 DAPI で染
色して観察する。このような解析により, 現在までミト コンドリアの形態と伝達に関与する 12 の遺伝子が報告 されている(6).

これらの遺伝子産物は，いくつかのグループに分類さ れる。一つは細胞骨格関連タンパク質である。アクチン 遺伝子 $(A C T 1)$ の突然変異体のいくつかでは，ミトコン ドリアの凝集が起こり，芽への伝達欠損がみられる。 $m d m 20$ 変異株では, アクチンケーブルの消失と同時に ミトコンドリアの芽への伝達が停止する。中間径フィラ メント様のタンパク質をコードする $M D M 1$ 遺伝子の変
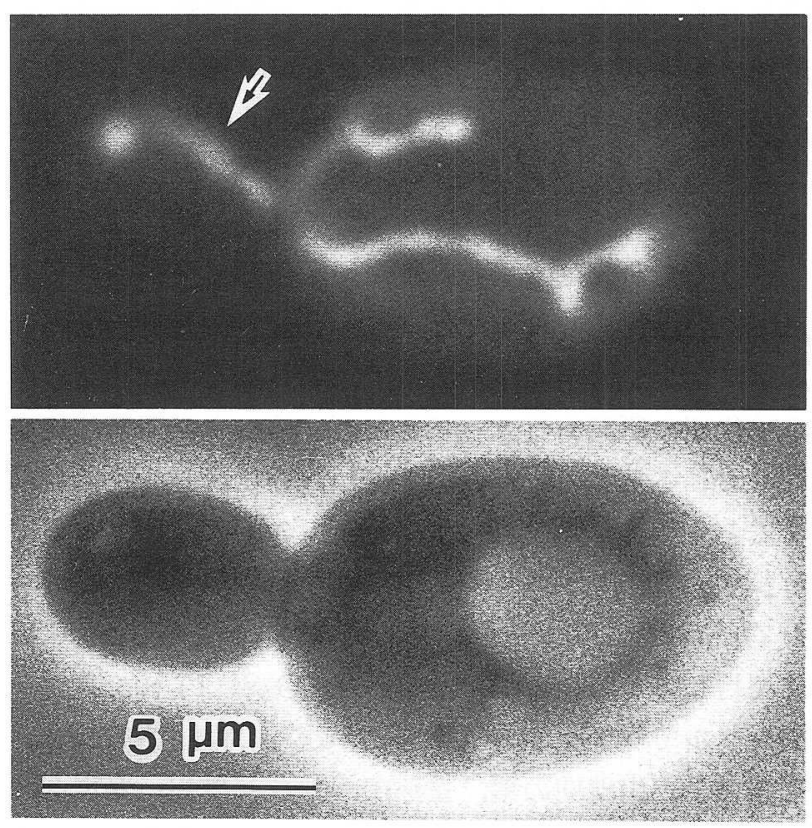

図 1 口膜電位依存性螢光色素 $3,3^{\prime}$-dihexyloxacarbocyanine iodide $\left[\mathrm{DiOC}_{6}(3)\right]$ で生体染色した酵母 ミトコンドリア ミトコンドリアは母細胞中で相互に融合して細胞を取り囲むよう な形態をとっており, 出芽時にミトコンドリアの先端が芽の中に 移動する (矢印)。写真では焦点が酵母の上半分に合っているため, ミトコンドリアの全体像は見えていない。 


\section{今日の話题 80}

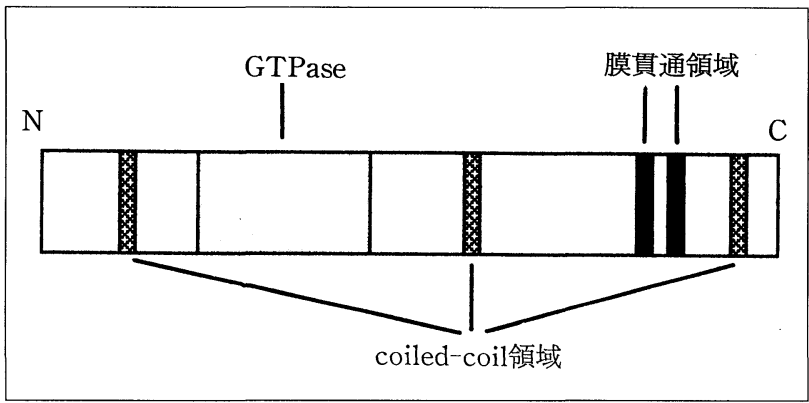

図 2 ・酵母 FZO1 遺伝子のドメイン構造

文献 9)より改変して引用.

異によっても，ミトコンドリアの形態異常と芽への伝達 阻害が起こる。一方, Mdm10p, Mdm12p, Mgm1p, $\mathrm{Mmm1p}$ などのミトコンドリア外膜タンパク質の変異 株や $\Delta 9$ 脂肪酸不飽和化酵素の变異株 $(m d m 2)$ において も, ミトコンドリアの凝集と芽への伝達阻害が起こる. 最近では, dynamin 様タンパク質の変異 $(d n m 1)$ のよ うに，ミトコンドリアは凝集しているが，伝達は正常な ものも得られている。しかし，これまで報告された突然 変異体の解析からは，ミトコンドリアの膜融合や分裂を 直接制御している遺伝子は見つかっていない.

これに対して，最近まったく別の方法でミトコンドリ アの融合を制御する新しい遺伝子が発見された。Drosophila の精子形成過程では, 減数分裂後の精細胞中でミ トコンドリアは顕著に融合して 2 つの大ミトコンドリ アを形成し，鞭毛軸系に沿って伸長する，ところが， fuzzy onion ( fzo) 遺伝子に変異が生じると, 精子ミト コンドリアの融合ができなくなり，不稔となることが Hales と Fullerにより発見された ${ }^{(7)}$. $f z o$ 遺伝子は新規 な高分子量膜貫通型 GTPase をコードしており，この 遺伝子産物は隇数分裂第二分裂後の精細胞のミトコンド リアにのみ検出される. そして, $f z o$ ホモログは哺乳 類, 線虫, 酵母に存在することが報告された。そこで, Rapaport ら (1998) と Hermann ら (1998)の 2 つのグル ープが酵母 FZO1 遺伝子の機能を解析した ${ }^{(8,9)}$. 酵母 Fzo1p は855アミノ酸からなり, Drosophila Fzo タン パク質と同様に,アミノ末端側の GTPase ドメインと C 末端側の 2 つの膜貫通ドメインをもち, 3 個所の coiledcoil 領域を含む新規な GTPase ファミリーを構成する (図 2).FZO1 遺伝子破壊株 $(\Delta f z o 1)$ は数個の小球状ミ トコンドリアをもち, mtDNA を欠失している.しかし, $\Delta f z o 1$ 株に $G A L 1-F Z O 1$ プラスミドを導入し Fzolp
の発現量と経時的なミトコンドリアの形態変化を詳しく 解析した結果と, 温度感受性 $f z 01-1$ 突然変異株でのミ トコンドリア形態の解析結果から, Fzolp の欠損により 網状ミトコンドリアがすみやかに断片化することが明ら かになった，酵母では接合型 $a$ と $\alpha$ の 1 倍体株を混合 すると亜鈴形の接合子を形成し，両親由来のミトコンド リアは接合子の中で融合する. しかし, $f z 01-1$ 変異株ど うしの接合過程では， $37^{\circ} \mathrm{C}$ 制限温度で両親由来のミト コンドリアの融合は起こらない.

Fzolp は網状ミトコンドリアの全体に分布しており， その GTPase ドメインを細胞質側に向けている外膜の 内在性タンパク質である. GTPase ドメインモチーフの 1アミノ酸を改変すると，ミトコンドリアの融合が阻害 されたことから，GTPaseドメインがミトコンドリアの 膜融合に直接関与していることが示唆されている. Fzolp は $\mathrm{N}$ 末端にシグナル配列をもたず，ミトコンド リア内膜電位に依存せずに，直接レセプターに結合する ことによって外膜に組み込まれると考えられる. ミトコ ンドリアを可溶化し，ゲル濾過にかけると，Fzolp タン パク質は $800 \mathrm{kDa}$ の高分子量複合体として溶出された。 分泌経路やエンドサイトーシスにおける小胞の膜融合 はv/t-SNARE タンパク質により仲介されているが，こ れらはミトコンドリアでは見つかっていない.ミトコン ドリア融合には機能的にまったく異なる内外 2 枚の膜を 連続的に融合させる必要があり，他の膜系とは異なる膜 融合装置が必要であると考えられる。

FZO1 遺伝子の発見を契機として，近い将来，ミトコ ンドリア膜融合装置の全貌が解明されることが期待され る.

1) T. Kuroiwa: Int. Rev. Cytol., 75, 1 (1982).

2) T. Kuroiwa, H. Kuroiwa, A. Sakai, H. Takahashi, K. Toda \& R. Itoh: Int. Rev. Cytol., 181, 1 (1998).

3) I. Miyakawa, H. Aoi, N. Sando \& T. Kuroiwa : J. Cell Sci., 66, 21 (1984).

4) I. Miyakawa, K. Higo, F. Osaki \& N. Sando : J. Gen. Appl. Microbiol., 40, 1 (1994).

5) I. Miyakawa \& Y. Yanagamizu : Protoplasma, 204, 47 (1998).

6) G.J. Hermann \& J.M. Shaw : Annu. Rev. Cell Dev. Biol., 14, 265 (1998).

7) K.G. Hales \& M.T. Fuller : Cell, 90, 121 (1997).

8) D. Rapaport, M. Brunner, W. Neupert \& B. Westermann : J. Biol. Chem., 273, 20150 (1998).

9) G.J. Hermann, J.W. Thatcher, J.P. Mills, K.G. Hales, M. T. Fuller, J. Nunnari, J. \& M. Shaw : J.Cell Biol., 143, 359 (1998).

(宮川 勇, 山口大学理学部) 


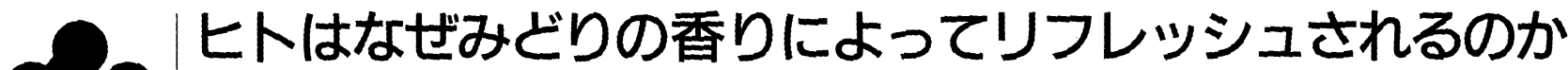 解明進む嗅覚神経・内分泌系・自律神経系・免疫系に与える影響}

人は森林浴で灌木・草本の葉から放散されるみどりの 香りに思わずほっとし，安らぎを覚える，みどりの香り は疲れた人の心をりフレッシュし，ストレスを解消する だけでなく，ストレスによって誘起する神経的，精神的 障害を自然態で治す，筆者はこの植物と七トの不思議な 関わりを実証すべく，植物の分野での生態・生理・生化 学・分子生物学, ヒトの嗅覚神経・脳神経機能・内分泌・ 免疫系, みどりの香りの化学構造と官能誘起相関, 心の 発現・精神の造成メカニズムの解明といった学際領域か らのプロジェクトを組織し, 研究を進めている(1).

筆者は 1957 年来, みどりの香りの研究に取り組んで きた。みどりの香りは，すべて炭素の数が 6 個の飽和・ 不飽和のアルコール，アルデヒドの 8 種の同属体, $n$-ヘ キサノール, $(3 Z)-,(3 E)-,(2 E)$-へキセノールと各々 のアルデヒドであることを単離・確認し，この香りは複 合の香りであることを明らかにした (1980). そして,こ の香りは葉緑体膜（構成中性脂肪，リン脂質）から， $\alpha-$ リノレン酸, リノール酸を前駆体に，13 位に $\mathrm{OOH}$ を添

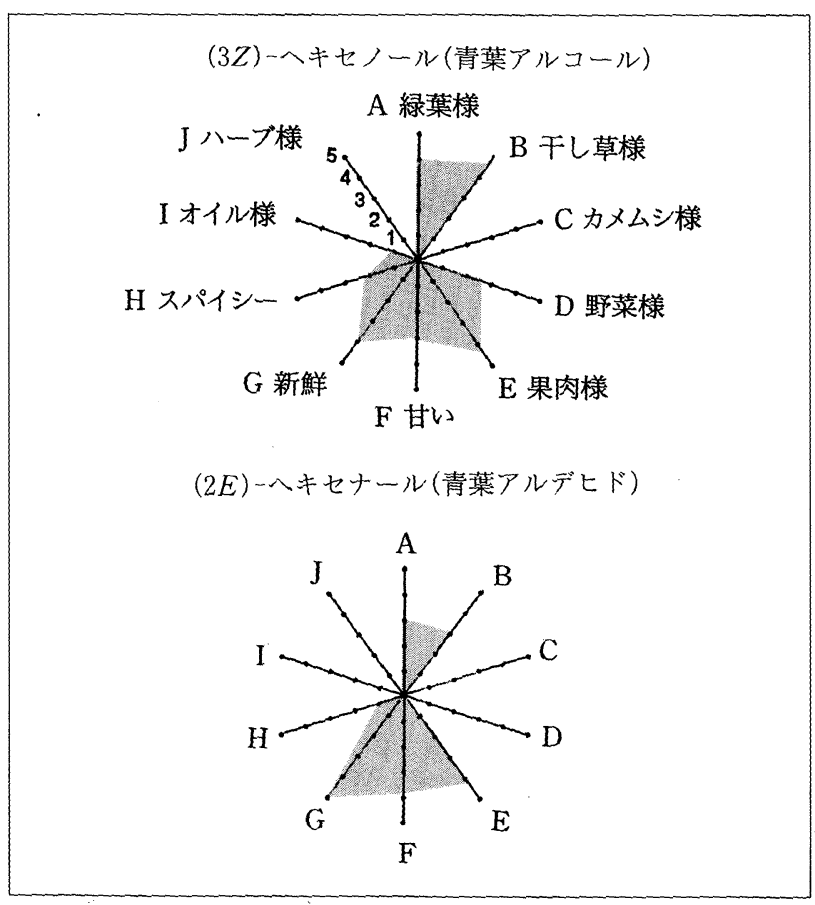

図 1・みどりの香りとヒトの官能相関（レーダーチャート） $\mathrm{A} \sim \mathrm{J}$ : 官能項目, 1 5 : 官能感度
加した $13(S)$-ヒドロペルオキシ中間体を経，次いで C12-C13 間の開裂により生成する $(1975)^{(2)}$ 。一方，これ らを生成する酵素の単離・精製やその性質の解明, 反応 のメカニズムを, 生理学・生化学・分子生物学の領域か ら明らかにした(3).

この香りは環境からのストレスによって生成し，その ときの各分子種の濃度のバランスはストレスの状沉によ って様々で，生物は互いの情報交換などに利用している (アレロパシー, フィトンチッド, フェロモン)。また, 森林の香りは, みどりの香りに加兄て, 緑葉や樹幹から 放散する一種馥郁とした香りのミックスである。後者は, 主として $\mathrm{C}_{10}$ のテルペン類で, 多様性のある生理活性作 用，たとえばヒノキからのヒノキチオールはシロアリの 殺虫作用などを呈する，この両者は互いに影響し合って 森の香りとして環境中に放出されている(4).

日本で森林浴の効能が唱えられ始めた 1980 年頃より, 筆者はみどりの香りにヒトがどのように官能するのかに ついて研究を始めた。まず，青葉アルコールと青葉アル デヒドを含む $\mathrm{C}_{6}$ のモノエン系のアルコール，アルデヒ ドすべての幾何・位置異性体 14 種を合成し，これらを用 いてヒトの官能試験を行なった ${ }^{(5)}$ 。ここでは, そのうち, 青葉アルコールと青葉アルデヒドのレーダーチャートを 示す(図 1)。パネラーは項目 $\mathrm{A} \sim \mathrm{J}$ の各香りを区別し,

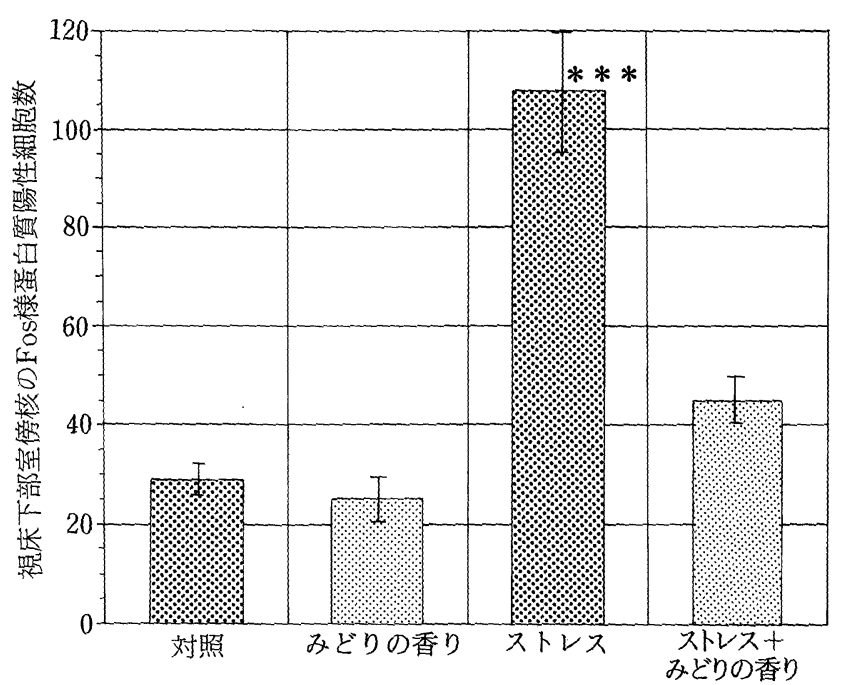

図 2 拘束ストレス解荷による梘床下部室傍核内 Fos 様蛋 白質発現に及ぼすみどりの香りの影響 


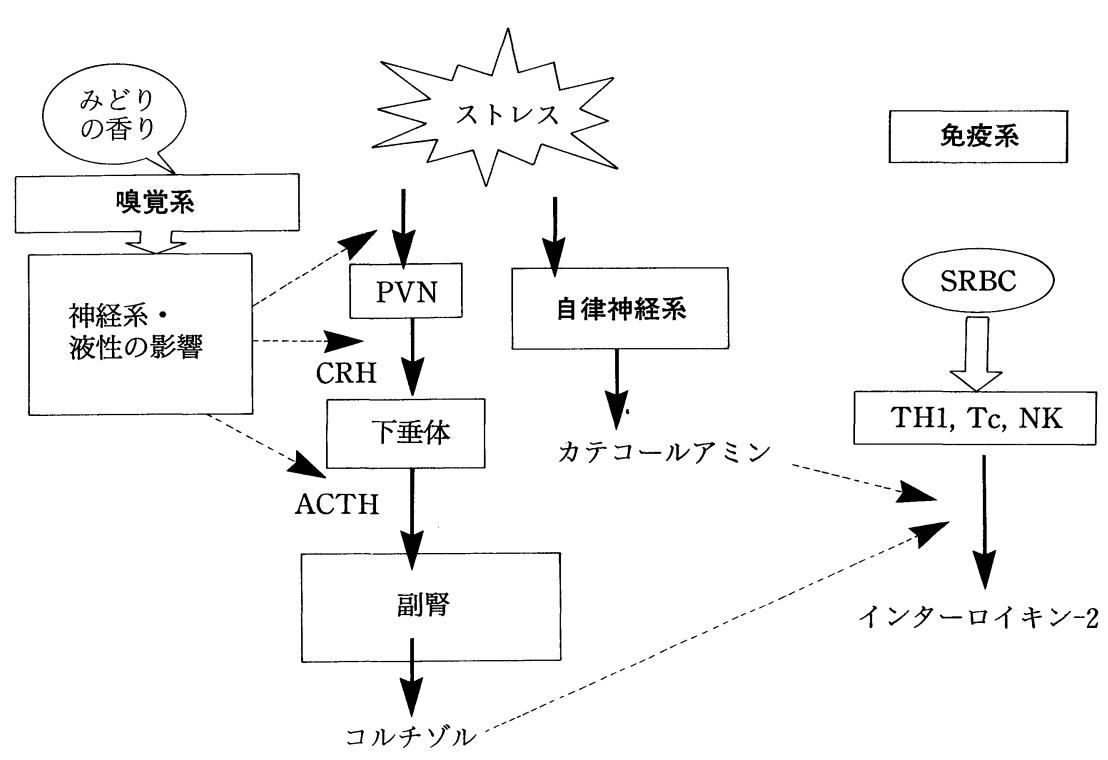

図 3 -みどりの香りの生体に及ぼす経路

PVN : 視床下部室傍核, TH1 : ヘルパー T 細胞, Tc：キラー T 細胞, NK : NK 細胞, ACTH : 副腎皮質刺激ホルモン, CRH : ACTH 放 出ホルモン

官能の強さを 5 段階に分け判定し, 評価 4 以上は特徵の ある項目とした。実験の結果, 青葉アルコールについて は, 緑葉の香り $\mathrm{A}$ と感じる人の官能感度は 4 , 干し草様 香 $\mathrm{B}$ は同じく 5 に近く，新鮮さを想起する香り $\mathrm{G}$ は 4 であった。一方，青葉アルデヒドに対しては新鮮さ $\mathrm{G}$ は 5 に近く, 果実様の香り $\mathrm{E}$ は 4 であった。このように, 両者はともに新鮮さが特徵である。ただし, 青葉アルコ ールは “青くささ”に特徵を呈し, 青葉アルデヒドは果 実様の香りに特徵をもつ. 特に青くささと化学構造との 間には, 他の実験 ${ }^{(6,7)} も$ 加えて検討し, 化学構造の中に $\omega 3 z$ を有することを見いだした。このことは，筆者らの 研究プロジェクトで目下展開中の嗅覚神経細胞受容体の 研究に重要な示唆を与えている(1).

みどりの香りによって，ヒトが快適さを感じたり精神 が安定するのはどうしてであろうか。 $\alpha$-脳波 (P 300*) の振幅を指標に調べた ${ }^{(8)}$. 振幅は意識レベルに対応し, 潜 時は神経伝達機能に関連する。緊張させる香りは振幅を 増加させ, 鎮静化させるものは減少させる.この感応試 験から, 青葉アルコールと青葉アルデヒドは各々の濃度 $0.03 \%$ で快適さ・心地良さを呈する. また，この濃度で青 葉アルコールと青葉アルデヒド両香をミックスして試験 すると, 各々単独の場合より快適さが増す.

*刺激提示約 300 ミリ秒後に発生する陽性波
1994 年以来，筆者はみどりの香りのヒトの免疫機能 に及ぼす影響について研究を展開している， $\alpha$-脳波や 心電図 (平均心拍数)の測定・解析から，これらの香りは 嗅覚系を介して視床下部・辺縁系に入り，内分泌系・免 疫系・自律神経系の広範な生体調節系に，また心理的な 影響をも与えることがわかった ${ }^{(9)}$.ラットのストレス負 荷時の副腎皮質刺激ホルモン $(\mathrm{ACTH})$ 変動実験に続い て, ヒツジ赤血球処置 (SRBC) 後の免疫系の活性化を指 標とするインターロイキン-2 (IL-2) の変動と, 視床下 部室傍核 (Paraventricular Nuclei ; PVN) や視索上核 に扔ける Fos 様蛋白質の発現変動を調べた ${ }^{(10)}$.その結 果, SRBC 感作ラットへの電気ショックストレス負荷に よる IL-2 変動に対するみどりの香りの影響は, ストレ ス非負荷時は SRBC 感作後 3 日目で IL-2 の上昇が認め られるが, ストレス負荷はこれを抑制, ストレス+みど りの香り提示により IL-2 は上昇を認めた. また, 拘束ス トレス負荷による PVN 内の Fos 様蛋白質発現に及ぼす 香りの影響については，ストレス負荷による PVN内 Fos 蛋白質が顕著に発現したが, ストレス負荷 30 分前に みどりの香りを嗅がせておくと発現は有意に抑制された (図 2).これらの実験から，みどりの香りは嗅覚系を介 し, 室傍核に神経性あるいは液性の何らかの影響を及ぼ すことにより，ストレス負荷による ACTH 放出ホルモ 
ン $(\mathrm{CRH})$, アルギニンバソプレッシン $(\mathrm{AVP})$ などの生 成·分泌上昇を抑制し，下垂体からの ACTH 分泌，それ によるコルチゾル (CRT) 分泌を抑制すると考えられる. 一方，ストレスは視床下部自律神経機能に対しても交感 神経系反応が強調され，カテコールアミン (CTA) 類の 分泌も上昇させる。これら CRT，CTA などは免疫系に 働き，免疫活性を抑制する。したがって，みどりの香り は内分泌・自律神経・免疫各系に作用することにより， ストレスによる生体反応を緩和し，免疫活性を高める作 用を有している（図 3）。

1）「ヒトは何故にみどりの香りによってリフレッシュされるの か! 」, シンポジウムシリーズ(1997〜 1999)講演要旨.

2) A. Hatanaka : 'Biosynthesis of so-called "green odor" emitted by green leaves', "Comprehensive Natural Products Chemistry”, Vol. 1, Elsevier Sci., 1999, p. 83.
3）畑中顯和：Foods Food Ingredients J. Jpn., 168, 4 (1996).

4) N. Agelopoulos, A. Hooper, S. Maniar, J. Pickett \& L. Wadhams : J. Chem. Ecol., 25, 1411 (1999).

5) A. Hatanaka, T. Kajiwara, H. Horino \& K. Matsui : $Z$. Naturforsch., 47c, 183 (1992).

6) Y. Sakoda, M. Katsui, T. Kajiwara \& A. Hatanaka : $Z$. Naturforsh., 50c, 757 (1995).

7）佐野孝太, 鈴木 潤, 畑中顯和：日本味と匂い学会誌, 6(3), 印 刷中 (1999).

8）菅野久信, 内田誠也, 佐藤信茂, 畑中顯和, 佐野孝太：日本味 と匂い学会誌, 3, 672 (1997).

9) S. Yamaoka, T. Tomita \& K. Watanabe : J. Physiol., 48 (suppl.), S. 229 (1998) ; Kanazawa, The Proceedings of the 75th Annual Meeting.

10）山岡貞夫，間中研一，今泉好偉，佐野孝太，畑中顯和：“緑の 香りの生体に及ぼす影響一その 2”, 第 76 回日本生理学会講演 要旨 (長崎), p.258, 1999 .

（畑中顯和，東亜大学植物生命学科）

\section{プロフィル}

岩 田 想 (So Iwata) 昭和 38 年 6 月 7 日生 $<$ 略歴 $>1986$ 年東京大学農学部 農芸化学科卒業/1991 年同大学大学院 博士課程修了/同年文部省高エネルギー 研究所特別研究員 / 1992 年ドイツ・マッ クスプランク生物物理学研究所研究員／ 1996 年スウェーデン・ウプサラ大学講 師 /1999 年同教授, 現在にいたるく研究 テーマと抱負 $>$ 膜蛋白質の $\mathrm{X}$ 線結晶構 造解析 $<$ 趣味 $>$ 旅行, 自動車・単車のレ ース

岩田 茂美（Momi Iwata） 昭和 42 年 8 月 6 日生 <略歴> 1990 年㧍茶の水大 学理学部化学科卒業 / 1992 年同大学大 学院修士課程修了/同年田辺製薬(株)勤 務/1997 年スウェーデン・ウプサラ大学 大学院博士課程入学, 現在にいたる 究テーマと抱負 $>$ 膜蛋白質の結晶化 $<$ 趣 味>北欧家具

宇育奈理努（Reed Wickner）1942 年 9 月 27 日生<略歴> 1962 年米国コー ネル大学卒業／1966年米国ジョージ夕 ウン大学医学部修了 (M.D. 取得) 後, NIH(National Institutes of Health), NIDDK (National Institute of Diabetes and Digestive and Kidney Diseases)生
化学・遺伝学研究室チーフ, 現在にいた るく研究テーマと抱負>プリオン，翻 訳, RNA ウイルス<趣味 $>$ 数学, 物理 学, 野球, 帆走, テニス

大橋-永田 恭子（Kyoko Nagata-Ohashi） 昭和 47 年 10 月 5 日生 $<$ 略歴 $>$ 平成 7 年九州大学理学部生物学科卒業／ 9 年同大学大学院理学研究科生物学専攻 博士課程入学, 現在にいたる。研究委託 により東北大学にて研究中 $<$ 研究テーマ と抱負 $>$ 細胞増殖因子の作用機構の解 析, 細胞骨格制御機構の解析 <趣味 $>$ 友 人との賭けない麻雀

木 村 光 (Akira Kimura) 昭和 11 年 6 月 18 日生 <略歴> 1959 年京都大学農 学部農芸化学科卒業／同年塩野義製薬 (株) 研究所勤務 $/ 1969$ 年京都大学農学 部食品工学科講師／1970 年同助教授／ 1977 年同大学食糧科学研究所教授, 現在 にいたるく研究テーマと抱負 >現在のテ 一マは酵母.アメリカ微生物学会からこ の 100 年のサイテーションインデックス の歴代 2 位を証明された。次の興味は, バイオマスから環境ホルモンフリーの生 分解性プラスチックを作ること<趣味 $>$ 初段主義
鈴木 平光 (Hiramitsu Suzuki) 昭和 24 年 3 月 30 日生 $<$ 略歴 $>1974$ 年東京水 産大学水産学部製造学科卒業 / 1976 年 同大学大学院修士課程修了/1982 年群 馬大学大学院医学研究科博士課程修了 (医博)／同年農林水産省食品総合研究所 入所 $/ 1991$ 年同研究室室長, 現在にいた る<研究テーマと抱負 $>$ シルバー（高譜 者）食品開発のための基礎研究＜趣味 $>$ 釣り，スキー

川畑俊一郎 (Shun-ichiro Kawabata) 昭和 32 年 7 月 16 日生 $<$ 略歴 $>1980$ 年 九州大学理学部生物学科卒業 / 1986 年 同大学大学院理学研究科博士後期課程修 了後, 同大学理学部助手 $/ 1997$ 年同助教 授, 現在にいたるく研究テーマと抱負 > レクチン, 抗菌ペプチド, フェノールオ キシダーゼ系などの先天性免疫の分子機 構＜趣味〉ようやく手に入れた望遠鏡を 使った自宅での天体観測

小林 英司 (Hideshi Kobayashi) Vol. 36, No. 4, p. 275 参照. 1999 年全薬工業 (株) 研究所退職

関沢 良之（Yoshiyuki Sekizawa） Vol. 36 , No. 4, p. 275 参照 